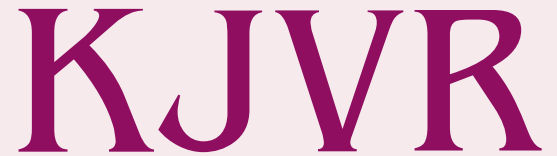

Korean Journal of Veterinary Research

\section{Original Article}

pISSN 2466-1384 · elSSN 2466-1392

Korean J Vet Res 2021;61(3):e18

https://doi.org/10.14405/kjvr.2021.61.e18

*Corresponding author:

Khalil I. Altaif

Department of Pharmacy, Faculty of

Pharmacy, Middle East University, Amman

11831, Jordan

Tel: +962-79-0353551

Fax: +962-6-4129613

E-mail: Kaltaif@meu.edu.jo

ORCID:

https://orcid.org/0000-0002-6342-4113

Conflict of interest:

The authors declare no conflict of interest.

Received: February 26, 2020

Revised: May 5, 2021

Accepted: May 13, 2021

\title{
Histopathological effects of the nematode Amidostomum acutum on the small intestines of two aquatic birds: Fulica atra and Gallinula chloropus
}

\author{
Khalil I. Altaif ${ }^{1,},{ }^{*}$ Furhan T. Mhaisen ${ }^{2}$, Aliaa H. Mizhir ${ }^{3}$ \\ 'Department of Pharmacy, Faculty of Pharmacy, Middle East University, Amman, Jordan \\ ${ }^{2}$ Independent Researcher, Katrineholm, Sweden \\ ${ }^{3}$ College of Education for Women, University of Kufa, Najaf, Iraq
}

The small intestines of two rallid aquatic birds (Fulica atra Linnaeus, 1758 and Gallinula chloropus (Linnaeus, 1758) from Bahr Al-Najaf depression, southwest of Al-Najaf city, mid-Iraq), were infected with the nematode Amidostomum acutum Seurat, 1918 with a prevalence of $25 \%$ and $50 \%$, respectively, and a mean intensity of 24.5 and 30 , respectively. The infected birds showed several gross pathological and microscopic lesions in their small intestines due to the infection with this nematode. The gross lesions included hypertrophy in the anterior part of the duodenum and small rough nodules on the small intestine wall. Microscopic lesions included necrosis and shortening of villi with their fullness with inflammatory cells, degeneration of villi, and an increased number of acini at the base of the intestinal villi.

Keywords: histopathology; nematoda; aquatic birds

\section{Introduction}

Fish-eating birds are definitive hosts of some helminth species of which the larval stages cause significant losses in fish breeding [1]. Birds of the family Anatidae are vulnerable to helminthiases, such as capillariasis, amidostomiasis, ascaridiasis, and hymenolepiasis [2].

Nematodes may be encountered in almost any organ of the birds, with the most common being the gastrointestinal tract, the duodenum and gizzard, and its adjacent dermal layers. They may be found in the skin, heart, and lungs [3]. In numerous early studies, Amidostomum spp. was reported to have pathogenic effects and cause the death of birds [4]. On the other hand, geese infected with Amidostomum spp. showed no serious lesions due to this infestation [5]. Tetrameriasis is a dangerous disease that infects birds and causes death [6]. The tissue destruction, degeneration, inflammatory response, hemorrhage, and necrosis were observed in the proventriculus of little grebe Podiceps ruficollis infected with the nematode Eustrongylides tubifex [7].

Amidostomum acutum was reported from Anas fluvigula in both Texas and Florida [8]. The mass mortality of the common eiders Somateria mollissima was reported in the Dutch Wadden Sea [9], but the authors were unable to attribute such death to a specific reason: food shortage, modern fisheries practices, anomalous environmental conditions, or high infection with the acanthocephalan Porfilicollis botulus as well as the infection with the gizzard nematode $A$. acutum in ad- 
dition to few other helminths.

The present article reports the different histopathological effects of the nematode A. acutum on the duodenum of two infected aquatic birds (Fulica atra and Gallinula chloropus) from Bahr Al-Najaf Depression, mid-Iraq, because such nematode affects the health of some important aquatic birds in Iraq.

\section{Materials and Methods}

Eight $F$. atra and four G. chloropus were dissected for a parasitological investigation. Both bird species belong to the family Rallidae, Order Gruiformes of the Class Aves [10]. The duodenum of both bird species was infected with the nematode $A$. acutum, which belongs to the family Amidostomatidae, order Strongylida, Class Secernentea of the phylum Nematoda [10]. A $1 \times 1 \mathrm{~cm}$ area of infected and uninfected tissue sections of the duodenum was selected, considering that the infected sections included a part of the lesion and an uninfected part. The sections were fixed with Bouin's solution for 24 hours, dehydrated with a graded series of ethanol, and then with a mixture of absolute alcohol and xylol, cleared with xylol, embedded with paraffin in paper cubes, and transferred to wax cubes [11].

The wax cubes were cut into 4 to 5 micrometers thick sections with a rotating hand microtome. The sections were placed on a slide, transferred to a water bath for 2 to 3 minutes at $37^{\circ} \mathrm{C}$, and then to a hot plate $\left(35^{\circ} \mathrm{C}-40^{\circ} \mathrm{C}\right)$. The Harris hematoxylin and eosin stain procedures were employed [12].

All birds experiments were performed in accordance with the guidelines of the National Council for Animal Experimentation Control, and the Ethical Committee approval was obtained from Ethical Committee of Middle East University, Jordan.

\section{Results}

Clinically, the infected aquatic birds were sluggish, emaciated, and unable to move. Furthermore, they lacked appetite as they refused to take food.

Macroscopically, the duodenum junction with the gizzard of both F. atra and G. chloropus was inflamed. Longitudinal cutting of this area showed a huge number of the nematode $\mathrm{A}$. acutum (Fig. 1), blocking the lumen and preventing food passage. Small rough solid nodules were also observed on the intestinal wall of both birds.

Microscopically, the most prominent feature was concerned mainly with villi because most of these structures showed atrophy, shortening, degeneration, and filled with inflammatory cells (Fig. 2) compared with their long and thin shape (Fig. 3).

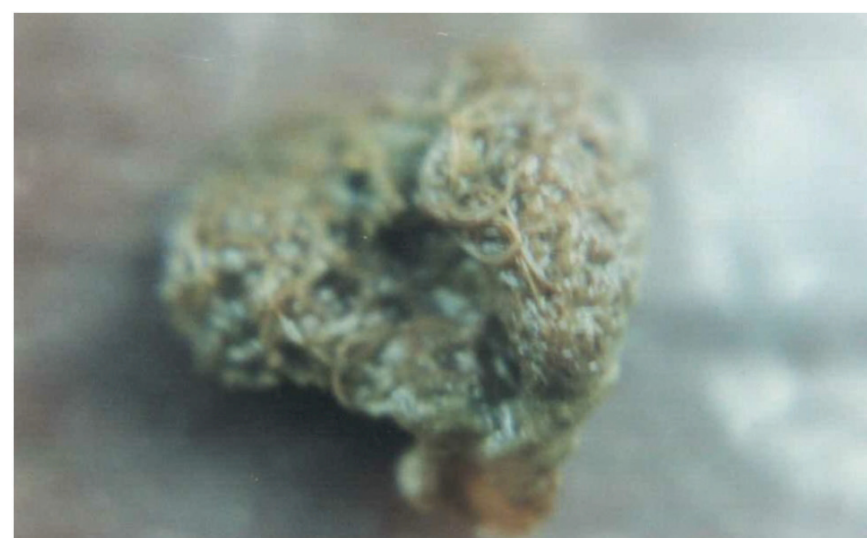

Fig. 1. Large mass of Amidostomum acutum inside the gut of the infected birds.

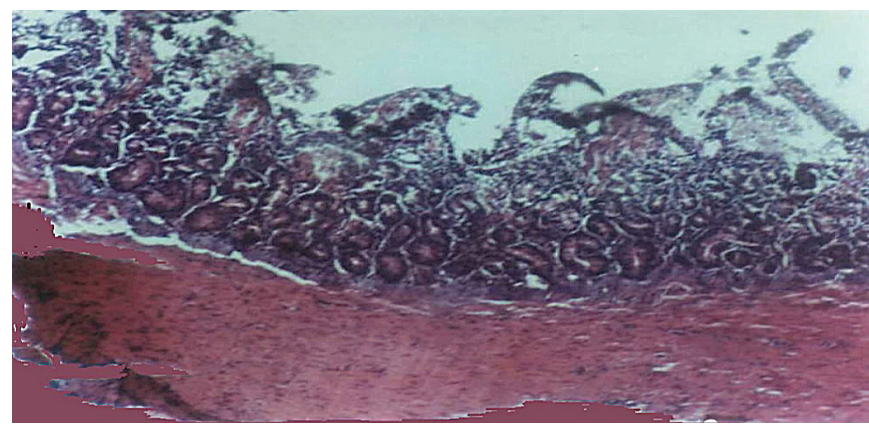

Fig. 2. Villi atrophy and hypertrophy in the gut of the infected birds with Amidostomum acutum (H\&E stain, $\times 100$ ).

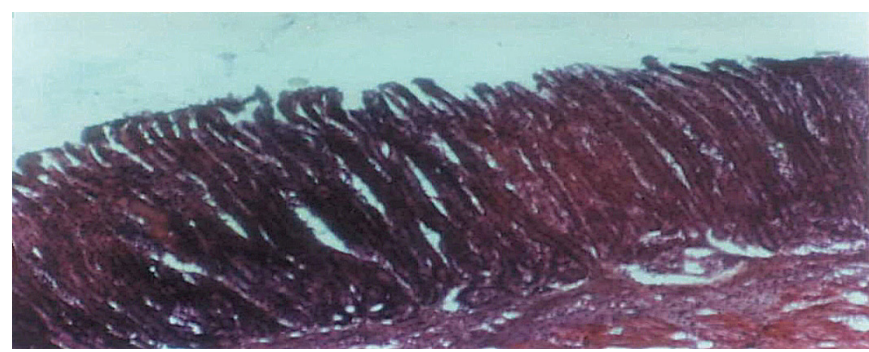

Fig. 3. Uninfected villi (H\&E stain, $\times 100)$.

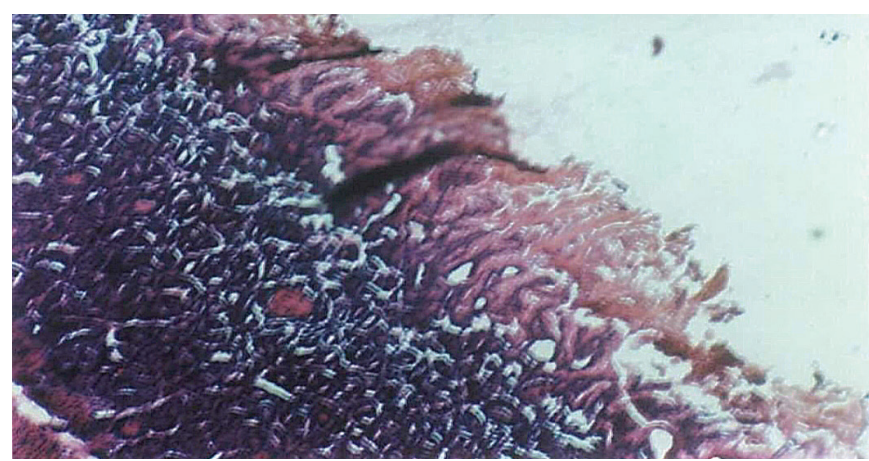

Fig. 4. Villi degeneration of birds infected with Amidostomum acutum (H\&E stain, $\times 100)$. 


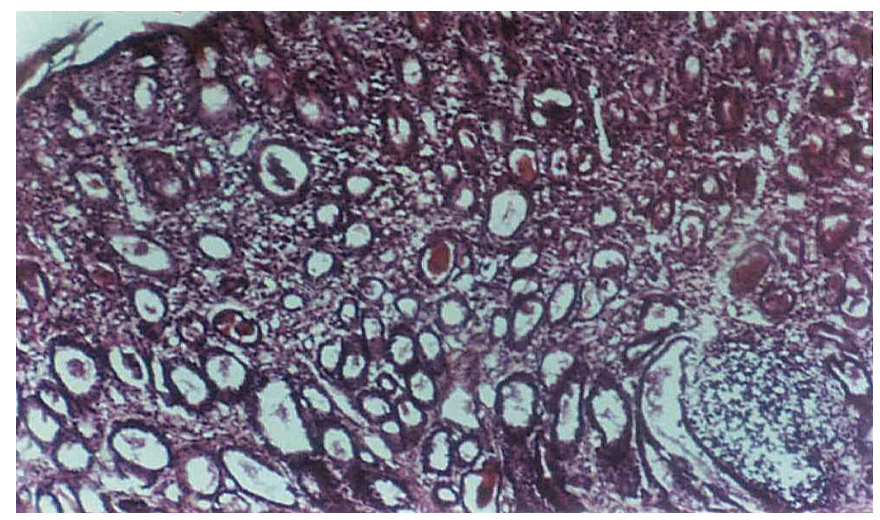

Fig. 5. Duodenal inflammation of the infected birds with Amidostomum acutum (H\&E stain, $\times 100)$.

The degenerated villi appeared cracked, loosened, and lost their normal appearance (Fig. 4) compared to the normal villi (Fig. 3).

A large number of chronic inflammatory cells were noted, which filled the entire intestinal villi. Such cells also occurred in both the muscularis mucosa and serosa of the intestine of both bird species (Fig. 5).

An increase in the number of acini found in the base of the intestinal villi was also observed. Such acini appeared in a single row in the uninfected intestine (Fig. 2).

\section{Discussion}

A. acutum causes severe damage to its host by initiating anemia in addition to mechanical injuries to the host tissues as it tries to penetrate deeply and cannot be removed [13]. Among the mechanical damage observed in the present investigation was the occurrence of nodules on the internal walls.

Atrophy of villi occurred because of direct contact between the worms and the apex of villi, which causes a decrease in the villi absorption efficiency and a decrease in the absorption of the digested food, solutions, and necessary minerals [14,15].

In the intestine of both F. atra and G. chloropus infected with amidostomiasis in the present investigation, the villi lose their normal shape. Such degeneration was also observed in chickens infected with the cestode Raillietina cesticillus [16], domestic ducks infected with the trematode Notocotylus attenuatus [17], and in domestic fowl, Gallus gallus domesticus, suffering from cestodiasis [18].

Clear intestinal inflammation in the current study was represented by chronic inflammatory cells (lymphocytes, plasma cells, and phagocytes). A similar finding was also observed in domestic ducks infected with the nematode Echinuria uncinata
[19]. Such lesions were observed as an increase in lymphocytes and eosinophils of domestic ducks infected with the trematode Sphaeridiotrema globulus [20]. An inflammatory response was noted in the proventriculus of the cattle egret Bubulcus ibis due to an infection with the nematode Microtetrameres egretes [21]. A similar response was also observed in the case of an infection of the little grebe $P$. ruficollis with the nematode E. tubifex [7]. The destruction of glandular secretory cells and a loss of secretory function of the proventriculus of the North Island kaka Nestor meridionalis septentrionalis were reported with a nematode Microtetrameres nestoris infestation [22]. The increase in the number of acini, which is found in the base of the intestinal villi, is caused by villi degeneration. Phalacrocorax carbo infestation with the cestode Haploparaxis crassirostris revealed the destruction of the villi epithelial lining and intestinal glands [23]. The present study confirmed the earlier results on the role of helminthic parasites on the health of aquatic birds.

\section{Acknowledgments}

The first author is grateful to the Middle East University (MEU), Amman, Jordan, for the financial support granted to cover the publication fee of this article (no. 2019MEU007).

\section{ORCID}

Khalil I. Altaif, https://orcid.org/0000-0002-6342-4113

Furhan T. Mhaisen, https://orcid.org/0000-0003-1062-1866

Aliaa H. Mizhir, https://orcid.org/0000-0002-4921-4654

\section{References}

1. Baruš V, Sergeeva TP, Sonin MD, Ryzhikov KM, Ryšavý B. Helminths of Fish-Eating Birds of the Palaearctic Region. I, Nematoda. Springer-Science Business Media, Dordrecht, 1978.

2. Marquardt WC, Demaree RS, Grieve RB. Parasitology and Vector Biology. 2nd ed. Harcourt Academic Press, San Diego, 2000.

3. Fagerholm HP. Nematode parasites of marine- and shore birds, and their role as pathogens. Bull Scand Sac Parasitol 1996;6:16-30.

4. McDonald ME. Catalogue of Helminths of Waterfowl (Anatidae). Special Scientific Report-Wildlife No. 126. U.S. Dept. of the Interior, Fish and Wildlife, Washington DC, 1969.

5. Nowicki A, Roby DD, Woolf A. Gizzard nematodes of Canada geese wintering in southern Illinois. J Wildl Dis 1995;31: 
307-313.

6. Wehr EE. Nematodes. In: Davis JW, Anderson RC, Karstad L, Trainer DO, eds. Infectious and Parasitic Diseases of Wild Birds. pp. 185-233, Iowa State University Press, Ames, 1971.

7. AL-Mayah SH, Mustafa FA. Pathological changes in the proventriculus of Podiceps ruficollis due to infection with Eustrongylides tubifex (Nitzsch, 1819) (Nematoda: Dioctophymidae) from Basrah, Iraq. Basrah J Sci B 1994;12:59-62.

8. Fedynich AM, Pence DB, Gray PN, Bergan JF. Helminth community structure and pattern in two allopatric populations of a nonmigratory waterfowl species (Anas fulvigula). Can J Zool 1996;74:1253-1259.

9. Camphuysen CJ, Berrevoets CM, Cremers HJWM, Dekinga A, Dekker R, Ens BJ, van der Have TM, Kats RKH, Kuiken T, Leopold MF, van der Meer J, Piersma T. Mass mortality of common eiders (Somateria mollissima) in the Dutch Wadden Sea, winter 1999/2000: starvation in a commercially exploited wetland of international importance. Biol Conserv 2002;106: 303-317.

10. Global Biodiversity Information Facility (GBIF). Free and open access to biodiversity data [Internet]. GBIF, Copenhagen, 2020 [cited 2020 Jan 2]. Available from: http://www.gbif. org.

11. Bancroft JD, Stevens A. Theory and Practice of Histological Techniques. 2nd ed. Churchill Livingstone, New York, 1982.

12. Humason GL. Animal Tissue Techniques. 2nd ed. W. H. Freeman Co., San Francisco, 1967.

13. Davis CL. Diseases of Wildlife. AFIP Review of Gross Morbid Anatomy of Animals. A. M. Best, Washington, DC, 1999.

14. Anderson WAD, Kissane JM. Pathology. 7th ed. Mosby, St. Louis, 1977.
15. Hollmén T, Lehtonen JT, Sankari S, Soveri T, Hario M. An experimental study on the effects of polymorphiasis in common eider ducklings. J Wildl Dis 1999;35:466-473.

16. Hofstad MS, Calnak BW, Helmboldt CF, Reid WM, Yoder HW Jr. Diseases of Poultry. 6th ed. The Iowa State College Press, Ames (IA), 1972.

17. Graczyk TK, Shiff CJ. Experimental infection of domestic ducks and rodents by Notocotylus attenuatus (Trematoda: Notocotylidae). J Wildl Dis 1993;29:434-439.

18. Rashid S, Tanveer S, Abdullah S. Histopathological studies of cestodiasis in domestic fowl, Gallus gallus domesticus. SM J Biol 2019;5:1020.

19. Ould P, Welch HE. The effect of stress on the parasitism of mallard ducklings by Echinuria uncinata (Nematoda: Spirurida). Can J Zool 1980;58:228-234.

20. Huffman JE, Roscoe DE. Experimental infections of waterfowl with Sphaeridiotrema globulus (Digenea). J Wildl Dis 1989; 25:143-146.

21. Al-Mayah SH, Mustafa FA, Al-Hadithi IAW. The morphology and pathological effects of Microtetrameres egretes Rasheed, 1960 (Nematoda: Spiruridae) from the Cattle Egret, Bubulcus ibis (L.), in Basrah, Iraq. Basrah J Agric Sci 1991;4:297-303. Basrah.

22. Clark WC, Black H, Rutherford DM. Microtetrameres nestoris n.sp. (Nematoda: Spirurida), a parasite of the North Island kaka, Nestor meridionalis septentrionalis (Aves: Psittaciformes). N Z J Zool 1979;6:1-5.

23. Khudhaier S, Al-Awadi HM, Mohammad AS. Histo-pathological changes in the three aquatic birds intestines due to parasitic infestations in the Bahr AL-Najaf depression Iraq. J Kerbala Univ 2008;6:101-106. 